\title{
Limitations of routine skeletal survey: detection of critical but asymptomatic cervical spine lesion in multiple myeloma
}

\author{
Syeda Sabeeka Batool, ${ }^{1}$ Ahmad Iftikhar, ${ }^{2}$ Aamir Nafees Ahmad, ${ }^{3}$ Faiz Anwer ${ }^{2}$
}

'Department of Medicine, Services Institute of Medical Sciences, Lahore, Punjab, Pakistan

${ }^{2}$ Department of Medicine, Division of Hematology and Oncology, University of Arizona Cancer Center, Tucson, Arizona, USA

Department of Medicine, College of Medicine - Tucson, University of Arizona, Tucson, Arizona, USA

Correspondence to Dr Faiz Anwer, anwerf@email. arizona.edu

Accepted 6 June 2017
CrossMark

To cite: Batool SS, Iftikhar A, Ahmad AN, et al. BMJ Case Rep Published Online First: [please include Day Month Year]. doi:10.1136/bcr-2017221231

\section{DESCRIPTION}

A 67-year-old asymptomatic man was found to have a total plasma protein level of $10.2 \mathrm{mg} / \mathrm{dL}$ on routine work-up. Serum protein electrophoresis (SPEP) revealed an $\mathrm{M}$ spike of $4 \mathrm{~g} / \mathrm{L}$ and an elevated IgG level of 4759 , and free kappa chain of $170.72(\mathrm{H})$, free lambda chain of $3.15(\mathrm{~L})$ and kappa:lambda ratio of 54.20. Bone marrow biopsy showed a kappa light chain restricted plasma cell neoplasm involving 20\%-30\% of marrow cellularity. Fluorescence in situ hybridisation (FISH) test demonstrated polysomy of chromosome 9 in $70 \%$, trisomy 11 in 57\% and trisomy 7 in 50.5\% of cells. Skeletal survey showed generalised mild osteopaenia with heterogeneous appearance of the osseous structures and a suspicious lytic lesion in the pelvis. To investigate bone lesion, full-body positron emission tomography scan demonstrated multiple

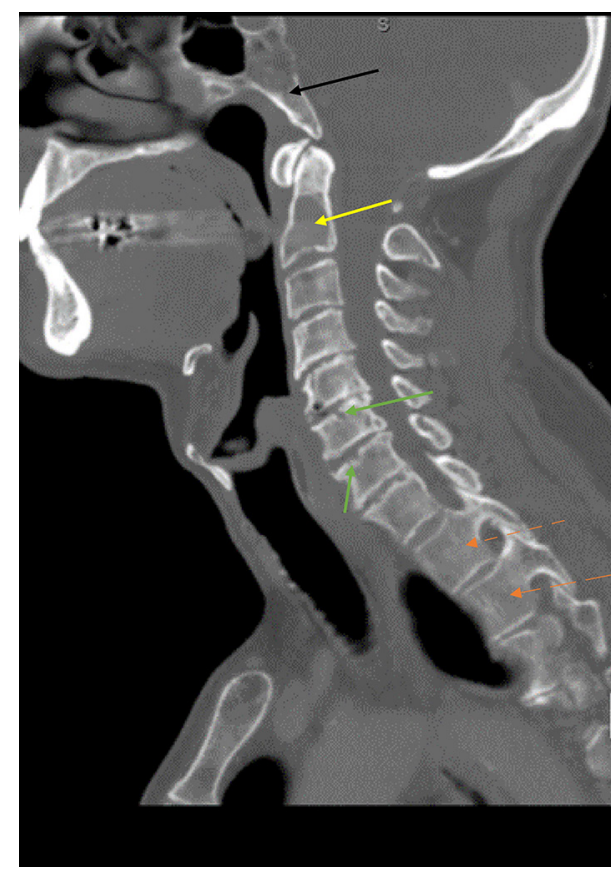

Figure 1 The neck showing a well-defined lucency in the body of C2 (yellow arrow). Focal lytic lesion in the clivus is present with breakthrough in the dorsal cortex (black arrow). There is disc space narrowing throughout the cervical spine with Modic type III sclerosis of the endplates and vertebral bodies (green arrows). Multiple small lucencies extend to the upper thoracic spine and are compatible with the patient's diagnosis of myeloma (dashed orange arrows). The largest of these is less than $5 \mathrm{~mm}$ in diameter. hypermetabolic skeletal lesions, with the dominant one involving the $\mathrm{C} 2$ vertebra showing a maximum standardised uptake value (SUV) of 11, suggesting viable myeloma. Neck CT confirmed lytic lesions in the body of the $\mathrm{C} 2$ vertebra, with intact cortical margins and no evidence of structural compromise (figure 1), so it was managed conservatively.

Myelomatous spine involvement is common, but cervical spine is the least common site. ${ }^{1}$ MRI better detects bone marrow involvement and extramedullary presentations. ${ }^{2}$ Myeloma lesions can be easily identified on MRI; the advantage of the CT scan is in its superior performance regarding bone integrity and stability, especially in cases of spine involvement. Whole-body ultra low-dose CT represents a useful diagnostic tool in the detection of spinal involvement of patients with multiple myeloma.

\section{Learning points}

- On diagnosis, patients with multiple myeloma routinely receive a skeletal survey, but positron emission tomography and CT scans are superior in detecting bone lesions.

- Myeloma lesions can be easily identified on MRI. The main advantage of the CT scan is its superior performance regarding bone integrity and stability, especially in the spine.

- Myelomatous cervical spine lesions are rare, and critical-appearing lytic lesions in the body of the cervical spine vertebra with intact cortical margins without evidence of structural compromise can be managed conservatively.

Contributors SSB contributed as the first author. SSB, Al, ANA and FA planned and designed the study. SSB, Al and ANA searched for relevant studies. SSB and Al developed the manuscript. ANA helped with interpretation of image. FA helped with final edits. FA is the senior author for this manuscript and will serve as corresponding author.

Competing interests None declared.

Patient consent Obtained.

Provenance and peer review Not commissioned; externally peer reviewed.

(c) BMJ Publishing Group Ltd (unless otherwise stated in the text of the article) 2017. All rights reserved. No commercial use is permitted unless otherwise expressly granted.

\section{REFERENCES}

1 Bier G, Kloth C, Schabel C, et al. Vertebral lesion distribution in multiple myeloma--assessed by reduced-dose whole-body MDCT. Skeletal Radiol 2016:45:127-33.

2 Rubini G, Niccoli-Asabella A, Ferrari C, et al. Myeloma bone and extra-medullary disease: role of PET/CT and other whole-body imaging techniques. Crit Rev Oncol Hematol 2016;101:169-83. 


\section{Images in...}

3 Ippolito D, Talei Franzesi C, Spiga S, et al. Diagnostic value of whole-body ultra-low dose computed tomography in comparison with spinal magnetic resonance imaging in

Copyright 2017 BMJ Publishing Group. All rights reserved. For permission to reuse any of this content visit http://group.bmj.com/group/rights-licensing/permissions.

BMJ Case Report Fellows may re-use this article for personal use and teaching without any further permission.

Become a Fellow of BMJ Case Reports today and you can:

- Submit as many cases as you like

- Enjoy fast sympathetic peer review and rapid publication of accepted articles

- Access all the published articles

- Re-use any of the published material for personal use and teaching without further permission

For information on Institutional Fellowships contact consortiasales@bmjgroup.com

Visit casereports.bmj.com for more articles like this and to become a Fellow 